\title{
Smuta: cyclical visions of history in contemporary Russian thought and the question of hegemony
}

\author{
Kåre Johan Mjør'
}

Published online: 22 January 2018

(C) The Author(s) 2018. This article is an open access publication

\begin{abstract}
In the post-Soviet context, various cyclical models of recurrent Russian "Times of Troubles" (smuty) have become increasingly popular. This perspective emerged first in Soviet dissident circles (Alexander Yanov, Aleksandr Akhiezer), who used it as a means to expose as mistaken the Soviet belief in continual historical progress on Russian soil. In post-Soviet Russia this critical approach has been continued by members of the "Akhezier circle," the economist Egor Gaidar, and others. Meanwhile it was given an affirmative, conservative reinterpretation by Aleksandr Panarin, according to whom Russia has always managed to overcome its phases of devastating Westernization and state collapse. This idea of Russian history has become influential; even Vladimir Putin has talked about Russia as a strong state able to survive various "Times of Troubles" from the early seventeenth century to the early post-Soviet period. It also figures prominently among members of the neoconservative Izborsk Club. This article analyzes different conceptions of Russian history as cyclical and their prominent place in the prevailing civilizational discourse of post-Soviet Russia. By means of postcolonial perspectives, this discourse is seen on the one hand as an attempt to question and reject Western hegemony, attempts that on the other hand nevertheless seem unable to liberate themselves from a normative dependence on the West.
\end{abstract}

Keywords Post-Soviet Russia - Time of Troubles (smuta) - Uses of history $\cdot$ Civilizationalism $\cdot$ Hegemony

Kåre Johan Mjør

kare.mjor@ires.uu.se

1 Institute for Russian and Eurasian Studies, Uppsala University, Uppsala, Sweden 
Кто-то говорит, что это заколдованный круг. Ну, хорошо, пусть круг - но это не тупик. Это карусель русской истории, которая никогда не наскучит. В четырнадшатом году третьего тысячелетия нам в очередной раз показалось, что мы летим в тартарары. А мы просто зашли на очередной круг.

Zakhar Prilepin, Ne chuzhaia smuta. Odin den' - odin' god (2015)

In post-Soviet Russia, different and at times conflicting forms of cyclical thinking have had a widespread appeal. "Cyclical thinking" means that cyclical patterns are imputed to various phenomena in virtually all fields. For instance, the authors of a book called The Space of Cycles (2007) make the claim that "analogical cyclicalgenetic laws may be found in the evolution of culture, morals, ideology, and all other spheres of society" (Baburin and Chistiakov 2007, 26). Likewise, the foreword to a 2013 collection of academic articles entitled Cyclicity: The Dynamics of Culture and the Preservation of Traditions states that "the cyclical pattern in history is one of the oldest in culture, and it has for ages ensured the work of the mechanism of culturogenesis (kul'turogenez) and the preservation of traditions, and [that] cyclicity is an indispensable element of the archaic worldview, which later continued and evolved in virtually all traditional cultures." The contributions to this publication, while mostly written by archaeologists and anthropologists, with a focus on ancient or "archaic" cultures, testify to a widespread interest in cycles as a constitutive feature of culture and history, and more specifically in "cyclicity as a form of preservation of traditions" (Al'bedil' and Savinov 2013, 5, 7). History is thus considered a field in which cyclical models are particularly applicable.

This article maps and explores different types of cyclical historical thinking in post-Soviet Russia, focusing in particular on how they are applied to Russian history. As I will show, they include a broad variety of models, ranging from the critical and liberal to the affirmative and conservative. However, they display a conspicuously similar structure, focusing on recurrent "Times of Troubles" (smuty) in Russian history, i.e., periods of breakdown and the subsequent struggle to recover. ${ }^{1}$ The article argues that the interest in such cycles is a reflection of the postSoviet condition: Cyclical models seek to explain regime collapse and the loss of great power status as well as to find meaning in history in the context of these traumatic events. The questions raised in this article are: What are the main features of the cyclical interpretation of Russian history? How has it been possible to use it for such different purposes, i.e. for both Westernizing-liberal and nationalistconservative means? And to what extent can it be regarded as a truly "indigenous" model? By indigenous I mean that the cyclical model is seemingly structured according to unique events in Russian history - the "original" Time of Troubles of the early seventeenth century, the 1917 Revolutions, the break-up of the Soviet Union. However, the writing of Russian cyclical history in all its varieties tends to involve the West in one way or another.

\footnotetext{
${ }^{1}$ Throughout this article, I have allowed myself to use in English the Russian term smuta and, on a few occasions, the Anglicized (and probably awkward) plural form smutas for Time(s) of Troubles. All translations from Russian are my own, KJM.
} 


\section{Russia: a postcolonial case?}

In post-Soviet historical thought, cyclical interpretations of history, of Russian history in particular, have evolved in close connection with the notion of "Russian Civilization." Post-Soviet Russia has experienced the gradual emergence of a "civilizational nationalism" that insists on a civilizational diversity in the world, promoting thereby a particularist agenda, or a Russian Sonderweg (Verkhovskii and Pain 2010; Linde 2016). And within this civilizational discourse, Russia is said to possess a unique cyclical historical logic. Both the idea that the world is made up of different civilizations and that civilizations unfold in cycles gained currency in postSoviet Russia after the collapse of the Marxist-Leninist paradigm and its linear, progressive conception of history (Scherrer 2003, 97). Civilizational and cyclical thinking has thus been a response to the post-Soviet condition of loss and trauma (Oushakine 2009). True, a linear scheme of history might have been hegemonic in the initial post-Soviet period as well, proclaiming the "end of history" and the defeat of a historical project rooted in the domestic culture (the Soviet Union). However, for those who were unwilling to accept this defeat as well as for those who doubted that this end of history would really include "us" (Russia), cycles and civilizations proved attractive as an alternative model for historical explanation and political mobilization.

Post-Soviet civilizational perspectives range from dialogical to confrontational, "Manichean" perspectives. While the late Grigorii Pomerants during the 1990s formulated a vision of a "concert" of civilizations, one of them being Russia (Pomerants 1998, 398), numerous others used the concept of civilization to develop anti-Western positions. An early, prominent proponent was the notoriously antiSemitic conspiracist Oleg Platonov, while a more recent example is Egor Kholmogorov, who in the introduction to his most recent book writes that "Civilization is the ability to say 'no'," an idea he attributes to Fernand Braudel (Kholmogorov 2016, 11). According to the currently prevailing versions of the civilizational paradigm, "Russian civilization" represents a unified whole-selfsufficient and isolated in the minds of some, actively interacting with its "Eurasian" neighbors according to others. In both cases the concept of civilization is a tool that serves to emphasize "cultural distinctiveness and singularity" (Linde 2016, 606).

Both the cyclical model of history and the civilizational paradigm have become tools for challenging Western hegemony, or what is perceived as such. The civilizational approach (tsivilizatsionnyi podkhod) proclaims that the world consists of incommensurable civilizations, and that no civilization may represent a template for the other ones. In this sense, the civilizational approach supports the currently hegemonic ideology in Russia of sovereignty, ideas of "nationalization," and the frequent insistence on autonomy from foreign influences (Morozov 2015, 141). By the same token, this perspective implies that the post-Soviet situation should not be seen as the "end of history." The cyclical logic implies that history will experience another turn of the cycle. A postcolonial approach is therefore, in my view, useful in order to analyze current Russian identity debates, where the idea of a Western hegemony is ubiquitous. The civilizational turn represents a clear example of a 
"refusal to acknowledge Western hegemony," to quote a standard definition of postcolonialism (Young 2003, 7). That we are not dealing here with a proper postcolonial experience is secondary to the fact that the situation, with its alleged lack of recognition, can be described as postcolonial (Gerasimov et al. 2013).

By implication, the civilizational turn in post-Soviet academic, political, and ideological discourses-i.e. the vast interest in "civilization" as both an object to be analyzed and an analytical tool, i.e. as a category of both practice and analysis ${ }^{2}$ may in all its varieties be interpreted as post-Soviet Russia's attempt to "provincialize Europe," to use a term coined by the theorist of postcolonialism Dipesh Chakrabarty; to conceptualize Russia outside the Eurocentric framework of "failure, lack and inadequacy" (Chakrabarty 2000, 34). According to many prominent Russian civilizationalists, "Europe" or the "West" does not represent universality or the benchmark of universal development-it is merely one among several civilizations. Thus, the main characteristics of Western civilization according to a majority of the Russian accounts-rationalism, individualism, progress - should not be seen as universal criteria of civilization(s). The civilizational perspective widely criticizes the evaluation of non-Western peoples (among which they include Russia) according to criteria such as (Western) modernization or modernity.

Although it may appear at first sight to be less critical than previous studies of Russian civilizationalism (e.g. Scherrer 2003; Laruelle 2004; Shnirel'man 2007), in that it takes the experience of non-recognition seriously, the postcolonial approach to contemporary Russia nevertheless enables us to see what Viatcheslav Morozov describes as Russia's "normative dependency" on the West, be it in terms of concepts and theoretical frameworks, of the West as a normative model, or simply of the inability to think about Russia without involving the West (Morozov 2015, 103-134). For instance, the extensive use of Western thought in order to reject the West often appears as contradictory (Aleksandr Dugin would be an example here). Another problem, which I find even more significant, is that attempts to "provincialize Europe" or the West often tend to operate with a simplified, monolithic model of the West, e.g. as "modernity" or "rationalism," the origins of which in the Russian case can be found in classical Slavophilism. The result is, as Frederick Cooper (2005) has pointed out in his criticisms of Chakrabarty and others, that the provincializing approach does not really provincialize Europe, at least not sufficiently, since it does not historicize Europe. Europe remains the unmarked signifier of modernity, or the "unmoved prime mover" (Aristotle). In Russia, we see this for instance in the writings of Sergei Kara-Murza (2011), who defines Russia as a traditional, collectivist civilization in firm, binary opposition to the Western civilization of modernity. Through such dichotomies, both Russia and Europe become "peoples without history" abstracted from the real historical contingencies and conflicts that have shaped them both. Moreover, as Cooper observes, the contributions of other parts of the world to modernity and modernization (for instance through colonialism) are likewise insufficiently acknowledged. In relation

\footnotetext{
${ }^{2}$ On "categories of practice" versus "categories of analysis," see Cooper $(2005,62-64$, co-authored with Rogers Brubaker).
} 
to Russia, it might be pointed out that the contribution of Russian thinkers to Western intellectual history is often ignored, in both Russia and the West. By implication, Europe or the West remains the main constituent other, despite the intention to liberate oneself from it.

In the following I will discuss further the issue of normative dependency on the West as the constitutive "other" by focusing on one of the defining characteristics attributed to "Russian civilization" in the post-Soviet civilizational discourse: its specific, even indigenous cyclical logic of time, temporality, and history. A commonplace in the civilizational discourse, as noted, is that the time of civilizations is cyclical. In fact, it is often unclear here whether "Western time," by contrast, is really linear and progressive, or if this is just a Western misinterpretation of reality, since the temporality of civilizations is otherwise defined as cyclical. However that might be, the idea of cyclical history appears in this context nevertheless as an inversion of linear time and thus of the "West" and notions such as "progress" and "modernity." By implication, we will see that concepts like civilization and cyclical history turn out to be instruments for identity formation rather than historical analysis.

\section{The origins of the cyclical interpretation (Akhiezer)}

In his memoirs, the White general Anton Denikin described the period of the Russian Revolution and Civil War as smuta, he even called them Sketches of the Russian Smuta. However, it was late Soviet dissidents who developed more elaborate cyclical models in order to explain what they saw as Russia's failures and lack of achievements in the past and present. A well-known example that reached the West in the Cold War era was the historian Alexander Yanov's scheme of a recurrent Time of Troubles in Russian history. Yanov emigrated to the West in the mid-1970s, and towards the end of that decade he was able to present his interpretations to a Western audience. According to Yanov (1978), Russian history from Ivan the Terrible to the post-Stalinist period has been made up of seven cycles, each consisting of three phases: pseudodespotism (e.g. Ivan the Terrible, Stalin), Time of Troubles (liberalization, reformist projects), and stagnation. Interestingly, Yanov's conception of the Time of Troubles was a positive one-he saw it as a period in which there was a search by a political opposition for alternatives to despotic government.

Yet more influential in the Russian context appears to have been a model that was proposed by Aleksandr Akhiezer, whose interpretation of the Time of Troubles was more critical. The economist and philosopher Akhiezer wrote his comprehensive Russia: A Critique of Historical Experience in the 1970s. The text circulated in samizdat, was confiscated by the KGB, but eventually published in 1991. ${ }^{3}$ This work projects a recurrent pattern of collapses and (pseudo-) recoveries onto Russian history. Authoritarianism has from time to time been undermined by anarchic protest from below, which in turn has always (thus far) been succeeded by a new

\footnotetext{
3 A new, expanded version came out in 1997 (Akhiezer 1997).
} 
return to authoritarianism. For Akhiezer this testified to the lack of a modern, differentiated society in Russia; it remained in many respects a heavily traditional society, due not least to its imperial burden-its administrative efforts have to a great extent been spent on managing vast territories (Akhiezer 2001).

Akhiezer, more specifically, divided Russian history into three "inversion cycles": one ending with the 1917 Revolution; one describing the Soviet period, and a final one beginning in 1991. Within the first cycle, furthermore, he discerned three different "catastrophes": the disintegration of the Kievan state, the "original" Time of Troubles at the turn of the seventeenth century, and the collapse of the Russian Empire during the First World War. Thus, Russian history up to and including the collapse of the Soviet Union presents us with four different "statehoods" and four "catastrophes." Although Akhiezer acknowledges that these collapses were caused by historically specific circumstances, his main interest lies in the structural similarities between them. In the early 2000s, Akhiezer interpreted the new president Vladimir Putin as returning to authoritarianism, thereby resuming "cycles of historical inertia" (Akhiezer 2006, 123).

In the 1990s, Akhiezer's analyses of the cyclical character of Russian history were developed further by a group of younger thinkers often referred to as the "Akhiezer circle": Viktor Ilin, Igor Kliamkin, Igor Kondakov, and Igor Iakovenko (see Swiderski 2010). While Akhiezer did on some occasions invoke the concept of "Russian civilization" in his analyses, these thinkers have claimed to a greater extent than Akhiezer that the inability of Russia to abandon various forms of traditionalism is a defining and thus an essential feature of Russian civilization. Clearly, this group represents a post-Soviet camp of Russian Westernism, though it remains questionable whether Russia according to their analyses is really capable of "becoming Western."4

\section{Russia and the west (Gaidar and beyond)}

A similar ambiguity may also be found in the writings of a far more famous figure in the post-Soviet world (who was not part of the Akhiezer circle): the economist and former prime minister of the Russian Federation, the late Egor Gaidar. In 1995, he published a book, The State and the Evolution, a title that reads as a response to Lenin's classic work, The State and the Revolution. Gaidar wrote this book at the time when he was trying to position himself as the leader of a new independent political party (Russia's Democratic Choice), though seen in retrospect this was rather the moment when his political career was about to end. In The State and the Evolution, Gaidar distinguished between a Western and an Eastern civilization, the main distinction between them consisting in the presence and absence of private property, respectively. According to Gaidar, Russia (the Soviet Union) was still by and large rooted in the Eastern civilization, though certain aspects of the Asian system had been left behind (Gaidar 2010, 190). As a recent analysis has pointed out, Gaidar combined in this book Neo-Marxist economic determinism (cf. Marx's "Asiatic mode of production," the difference in the distribution of property in the

\footnotetext{
${ }^{4}$ On the deterministic civilizational analyses of this group, see Mjør (2017).
} 
East and the West) with the "language of perestroika"- the belief in the freedom to choose different paths of development (Atnashev 2015). In any case, Russia as it appears in Gaidar's historical—and at times Orientalizing — account is characterized by a constant cyclical alteration between state consolidation and state disintegration, the latter taking place when bureaucrats privatize state property and accumulate it for their own benefit. Although in reality these tendencies have, as Gaidar sees it, made the state weak and prevented growth, the result has been a continual reemergence of new authoritarianism and a "cult of the state" (gosudarstvennichestvo). The shift from oligarch capitalism to state capitalism in the 2000s was for Gaidar a confirmation of this pattern (Gaidar 2010, 186; see also Gaidar 2009).

Gaidar proposed a similar cyclical interpretation in a later work published in 2009 entitled Smutas and Institutions (Gaidar 2009); but here he was more concerned with the stability and fragility of state institutions than with private property as an institution. Still, from this perspective, too, collapses in Russia take on a cyclical character and are due to various internal crises caused by both economic and institutional shortcomings. Smuta as defined by Gaidar is the period when the old authorities are no longer in power but have not been properly replaced. It is the period of chaos and lack of order, without state monopoly on violence, and without properly functioning institutions. It means social disorder.

Historically, Gaidar sees smuta first and foremost as a conflict between a centralizing state and protesting tax-paying farmers. This was the background for the "first" Russian smuta at the turn of the seventeenth century. The subsequent Times of Troubles in Russian history are, in Gaidar's account as well, the 1917 Revolutions and the collapse of the USSR. However, Gaidar claims that his model has universal applicability: The three Russian smutas are examples of what happens when popular revolts undermine state institutions. The French Revolution was a confirmation of the same process. "Anarchy, the de-institutionalization of society in the years of smuta and revolutions foster similar problems and have similar grounds" (Gaidar 2010, 99). In this sense, Russia is therefore not a civilization in its own right, with some indigenous historical logic. Those who were closer to Akhiezer, by contrast, tended to conceptualize Russia as a proper civilization, and for them the task of breaking the vicious circle was far more difficult, maybe even impossible. However, determinism ("Russia's Asian way") is also present in Gaidar's models and inevitably challenges the idea of Russia's free choice, which he otherwise actively propagated in the 1990s.

An even more recent example of a critical and yet determinist analysis of the dysfunctional Russian civilization and its lack of historical progress can be found in a book entitled The Spiral of Russian Civilization: Historical Parallels and the Reincarnation of Politicians: Lenin's Political Will, published by an author who calls herself Olga Khelga (2012). ${ }^{5}$ This story is also structured according to recurrent smutas, whose overcoming represents the beginning of a new circle in the Russian historical "spiral." "Spiral" does not imply a progressive evolution, however. The "first power spiral" was the Riurik dynasty, the second the Romanov dynasty, and the third the Soviet Union, while a fourth began with Putin's rise to

\footnotetext{
5 In a more recent edition of this work from 2016, the author is called "Olga Gorshenkova."
} 
power. In this account, Russian history is made up of almost identical analogous situations - the years from 1989 to 2000 correspond to the period 1905-1917, to mention just one of the numerous examples given by the author. Not only do similar events reoccur throughout Russian history; likewise political figures have conspicuously parallel features and roles. The Putin/Medvedev tandem is compared to Filaret and Mikhail Romanov, but Putin is also compared to another strong leader, Lenin-thus the somewhat surprising reference to "Lenin's Political Will" in the subtitle of the book. By focusing on Russian leaders and their contexts the author detects an exact correspondence between the different circles of the spiral, which she also visualizes graphically (see Fig. 1).

In general, the book is filled with condemnation of Russia's lack of sound development. Particularly noteworthy is the book's long account of the Yukos case, in which the author is clearly sympathetic to Khodorkovsky, claiming that his case has a clear parallel to measures taken during the first years of Stalin's reign. And while Putin "is Lenin," 2012 marked the beginning of the "age of Stalinism." "The people are so tired of the contemporary smuta that they happily follow and believe in their leader" (Khel'ga 2012, 487).

In many ways the book by Olga Khelga borders on the Akhiezer tradition in that it locates Russia's main problems in the militarization of the economy, bureaucratization, authoritarianism, and disrespect for dissent. However, it involves also a mythological and even astrological level of explanation, where the Russian historical spiral is segmented into twelve parts corresponding to planetary

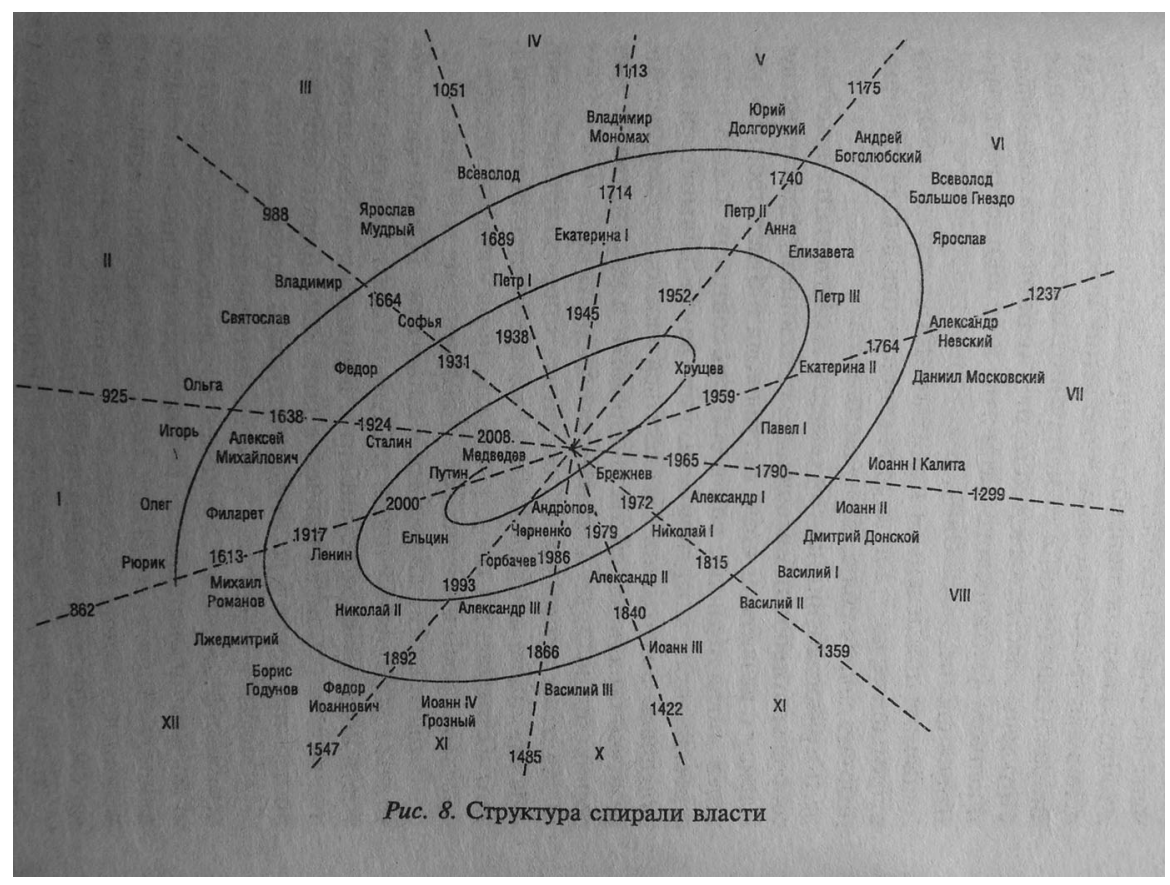

Fig. 1 (Khel'ga 2012, 441) 
movements and zodiac signs, where Russian rulers reflect the meaning of the zodiacs (Khel'ga 2012, 419, 440). It contains even numerous references to "karma" and "fate," and when the author towards the end starts deciphering the meaning of the letters of the name "Ilich," in order to demonstrate the parallels between Lenin and Putin, one might wonder whether all this is meant seriously. And yet the conclusion of the book returns to a straight-forward critique of the Russian authorities' failure to master the economy. Apparently, economic issues are solvable, but such an "exit from the crisis" is undermined by strong determinism. On one and the same page, the author is able to say that "the development of any country is dependent on its economy and system of governance of society" and that "time, organized in a specific way and regulated by cosmological laws, governs the peoples and the world. [...] We are slaves of our time, and each people possesses its own course of time, its own spiral of time and development" (Khel'ga 2012, 426).

\section{Russia as a post-industrial synthesis (Iakovets)}

A different type of analysis of Russia's cyclical, civilizational logic can be found in the writings of the economist Iurii Iakovets. In 1999, he published a book titled Cycles, Crises, Prognoses, which contains far more positive visions of Russia's future. This year he also established the Pitrim Sorokin/Nikolai Kondratiev International Institute. The book is presented on its colophon page as a "manifesto" of the "School of Russian Cyclicism" (shkola russkogo tsiklizma)—a new, revolutionary paradigm for the social sciences in the post-industrial era. The origin of this school, as Iakovets presents it in the book's Introduction (entitled "Russian Cyclicism"), goes back to early twentieth-century Russian thought, and includes Nikolai Berdiaev, the cosmists Vladimir Vernadskii and Aleksandr Chizhevskii, but first and foremost the economist Nikolai Kondratiev and the sociologist Pitrim Sorokin. This alleged current is subject to extensive celebration in this book. According to Iakovets, Russia has been an "epicenter" of cyclical thinking in the past, and it will reemerge as such a center in the near future (Iakovets 1999, 6, 12, 14, 207-208, 222, 394).

Iakovets describes cyclical processes on virtually all levels of nature and society, seeking thereby to demonstrate the applicability of the cyclical perspective. Still, his main interest appears to be in historical cycles. What has traditionally been described as "phases," "periods," or "epochs," is here redefined as "cycles," the Middle Ages being one cycle; the Renaissance another cycle, etc. The reintroduction of well-known currents, periods or facts as cyclical can sometimes take surprising turns, as when Iakovets presents Marxism as a cyclical theory, according to which feudalism represents one cycle, capitalism another.

Iakovets provides detailed accounts of different kinds of cycles in world history-from overall global historical cycles that encompass all fields of human activity to cycles in, for instance, cultural history. These are as a rule followed by a description of the corresponding cycles of Russian history, i.e. of a local cycle. Up to the present, Russia's cyclical phases, such as industrialism or the Enlightenment (the latter being a cycle of education and science), have normally taken place with a 
delay as compared to the West. Hence, Russia has so far played a peripheral role in the cyclical unfolding of history. In addition, the Russian historical cycles appear in Iakovets's account to have been characterized from time to time by complete breakdowns. However, by means of statistics Iakovets claims that this time lag has gradually decreased, and that Russia, in the shift from the industrial to the postindustrial cycle, will catch up with the remaining world and even play a pivotal role. In comparison with the "well-fed and self-satisfied" countries and civilizations of the world, Iakovets argues, Russia possesses significant advantages in terms of spirituality and human resources for the global transition to a post-industrial society. This transition on a global level, then, will also inaugurate Russia's rebirth, which Iakovets predicts with reference to the past and the cyclical logic of history: It has happened before and will therefore happen again. Although he acknowledges the possibility of yet another total collapse, he firmly believes that a full rebirth will be the outcome. And Iakovets proclaims that prognoses like these are possible and reliable through a correct understanding of the "historical rhythm" (Iakovets 1999, 241).

In addition to being a "cyclist," i.e. one who sees cycles as the fundamental structure of the world, Iakovets is also a "civilizationalist." He has published extensively on civilizations, most notably textbooks such as History of Civilizations (1990s, several editions) and the five-volume Civilizations (2006-2008). While explicitly distancing himself from the more nationalistic thinkers who in the 1990s wrote on Russian or Eurasian civilization (Aleksandr Panarin, Oleg Platonov), Iakovets, too, sees Russia as forming a civilization of its own-not isolated but interacting with the universal civilization as such, in particular at present, on the threshold to the new "super cycle" (Kondratiev's term) of the post-industrial society. It goes without saying that the time of civilizations according to Iakovets is cyclical, and on this point his ideas are in agreement with one of the central assumptions of the post-Soviet civilizational turn.

How, then, does Iakovets understand "Russian cyclical time" more specifically? In fact, in his 1999 book he did not use the notion of smuta to any significant degree. Instead, he singled out the following five main cycles of Russian civilization: 500 BC-1000 AD; Kievan Rus' up to the Mongol Invasion; Muscovy and the Romanov Empire up to and including Catherine the Great; the industrial era (nineteenth and twentieth centuries), and the emergent post-industrial age (Iakovets 1999, 185-186). This scheme clearly corresponds to Iakovets's overall idea of universal history and he seeks thereby to demonstrate that Russian history matches world history. However, in an article published the subsequent year he operated with a different scheme of cycles, which was structured more directly according to events in Russian history, and which resembled the model encountered above: the alteration of periods of strong statehood with periods of state collapse, the latter being defined as smuta. According to Iakovets, too, the periods distinguished by recurrent smutas are Medieval Russia before the rise of Moscow, Muscovy, the Romanov period, the Soviet period and finally the post-Soviet period (Iakovets 2000).

Thus, Iakovets appears to have adopted Akhiezer's scheme of Russian history, which represents a seemingly more indigenous model for the logic of Russian history, created on the basis of local events and not according to the above Eurocentric pattern 
with which Iakovets otherwise operated-Eurocentric because it is centered on the history of the Western world where "industrialism" was such a pivotal stage. As the adoption of this scheme by other post-Soviet intellectuals shows, however, the smuta model, too, contains a normative dependency on the West.

\section{The conservative reinterpretation (from Panarin to Putin)}

In the early 1990s, the philosopher Aleksandr Panarin was close to the Akhiezer circle. Having emerged earlier as a firm Westernizer, he gradually shifted his position and became during the 1990s highly critical of globalization and Western hegemony worldwide, due to its alleged devastating impact on Russia. A significant expression of this critique can be found in a book that he published in 1998 titled The Revenge of History. Interestingly, this book was even praised in a Western academic journal for challenging Western hegemony, in particular the claims of Francis Fukuyama and Samuel Huntington (although Panarin did share some affinity with the latter). Moreover, the reviewer gave Panarin credit for his rejection of worldwide "America-centrism" and its "double standards" (Bazhanov 1999). By the way, the accusation that the West operates with "double standards" has become ubiquitous in Russian political discourse. Today, it is remarkable to read such a positive review essay in a Western scholarly journal of a book by Panarin, a leading Russian Neo-Eurasianist, but at least the reviewer was precise in pointing to one of Panarin's chief aims: to reject Western hegemony. In the 1990s, Panarin emerged as a postcolonial thinker.

His new interpretation of Russian history is based on a reinterpretation of Akhiezer's scheme in which smuta is no longer seen as an inherent systemic crisis, but rather as the result of the dominance of westernized elites who in such situations abandon "the soil," the people, and the Russian or Eurasian civilization. Like Gaidar, Panarin, too, blamed the nomenklatura, but for a completely different reason: its main fault was its enthusiasm for the "wrong" civilization, defined here first and foremost in spiritual rather than economic terms, though with important economic consequences. What Panarin did was to reinterpret a framework initially proposed for a critical analysis of Russian history, now putting the main emphasis, on the one hand, on crises as the result of westernization and, on the other, on the recurrent ability of the Russian state to recover from these assaults. This was meant to apply not least to its last collapse: 1989 and the fall of the communist world should in the long run not be seen as the "end of history" (Fukuyama), but as occasioning another hegemonic shift in favor of Russia/Eurasia, a shift that would guarantee civilizational diversity in the world. Thus, Panarin's model involved as well a universalistic claim, grounded not in Western modernity but in his own vision of Russian Eurasia as the embodiment of a cultural balance between East and West, Christianity and Islam, Slavic and Turkic peoples (Panarin 2005; Mjør 2017, 51-53).

Panarin's contribution was crucial, I argue, in (re-)introducing a scheme of Russian history as made up of an alteration of stable state power and disintegration initiated by the elites. This "iron law" of Russian history has since become popular 
in Russian post-Soviet discourses, in particular among the more conservative circles. It serves to reject various forms of modernization projects and presents state preservation as an overall goal (Medushevsky 2013, 177). In 2012, it even reached the presidential level. On the eve of the presidential election Vladimir Putin used the notion of "Time of Troubles" in the plural ("the first Russian smuta") in order to emphasize that the Russian state time and time again has been able to recover from chaos-most recently during his own presidency (Putin 2012). ${ }^{6}$ By combining this historical scheme with the notion of Russia as a "state-civilization" (gosudarstvotsivilizatsiia), Putin and his speech writers adopted the language of contemporary Russian conservatism and its program for a "restoration of the future." It was Russian conservative thinkers who had previously coined the concept of "statecivilization" as an alternative for "empire," designating a state made up of many nationalities but dominated by the Russian one (Remizov 2005; Leont'ev 2005).

Another prominent figure who has recently applied a similar scheme is Patriarch Kirill who has also emphasized, more forcefully than Putin, that state disintegration is the result of various kinds of foreign intervention (including the westernization of local elites). He has stated that the main cause of the early seventeenth-century crisis was foreign intervention in the guise of a duplicitous local elite aiming to "modernize" Muscovy. He claims, moreover, that today a similar threat of imported alien models undermining Russian "sovereignty" is all too evident. According to the Patriarch, the 1990s had been a smuta similar to that of the early seventeenth century as well as to that of the early twentieth. Smuta, then, means the attempt to modernize Russian civilization and its indigenous "codes" (quoted in Torbakov 2014, 146-148). Previously, the use of smuta among clerics, as a name for modernization and/or Westernization, had been widespread in the more extremist circles of the Russian Orthodox Church, most notably in the infamous anti-Semitic writings of Ioann, Metropolitan of St Petersburg and Ladoga (Ioann 1995). Currently, however, it is also used by the Patriarch.

\section{Competing historical logics}

A central place in the post-Soviet civilizational discourse is occupied by seemingly obligatory discussions of classical civilizational doctrines-from Nikolai Danilevskii, Oswald Spengler, and Arnold Toynbee to Lev Gumilev, and even Samuel Huntington. ${ }^{7}$ Except for Huntington, they all operated with long, curve-like time spans of civilizations, of slow growth, flourishing, and decay. These models are given much attention, not least since all in one way or another single out Russia (or Eurasia, or the Slavic World) as an independent, self-sustaining civilization, which, in contrast to Western civilization, has not (yet) reached the stage of decline. Several writers endorse for instance Gumilev's model, according to which Russia still awaits a "golden autumn." However, the seeming collapse of Russian

\footnotetext{
${ }^{6}$ For an analysis of Putin's use of the smuta concept, see Petersson (2013).

7 A recent example is Gvozdev (2016).
} 
statehood during perestroika poses as well a theoretical problem, since it does not confirm the civilizationalist assumption about decays as a long process. ${ }^{8}$

This contradiction can be observed for instance in Sergei Redkozubov and Nikolai Sokolov's book of 2008, The Origins, Essence, and Fate of Russian Civilization. At the outset, the authors adapt Lev Gumilev's theories to the civilizational discourse by describing Russian civilization as being 500 years younger than Western civilization and as formed over a "thousand-year-long" period through a symbiosis of Tatar statehood and Orthodoxy. However, the book's conclusion introduces a different model of Russian history:

Our "original sin" is the terrifying collapse of morality at the top of society and the weakening of statehood that are repeated from one historical epoch to the next. Almost always the weakness of power is generated by envy, greed, and egoism, the moral degradation of the ruling minority (Toynbee), which opposes itself to the majority of the people. This is how it was before the Tatar-Mongol invasion, and it was repeated around four hundred years later during the Great Smuta. This is how it was in the last years of the Romanov Empire. This is how it was in the years of perestroika, and how it continued in the years of reform at the turn of the third millennium (Redkozubov and Sokolov 2008, 111).

What the authors describe here is not the model of civilizational development according to Gumilev or Spengler or Danilevskii, but rather the late- and postSoviet model of Russian history as made up of a series of Times of Troubles alternating with strong statehood. A similar book project by the same publisher, Russian Civilization and the Fate of Orthodox Russia by Boris Morozov (2014), opens, likewise, with a presentation of the classical civilizational doctrines (Danilevskii, Spengler, Toynbee) as well as some post-Soviet contributions. On this basis, Morozov defines Russian civilization in terms of geographical space, Orthodoxy, statehood, "national values"- -and finally the cyclical character of its history. The latter is defined on the one hand as one long life cycle (in accordance with the classical doctrines); on the other as a series of distinct phases: "Emergence" (up to the Mongol invasion), "Consolidation" (up to the early seventeenth century smuta), "Confirmation" (up to the turn of the twentieth century), "Breakdown" (the twentieth century) and finally "Transformation" (beginning with the turn of the twenty-first century). In particular, the last stage, which is actually presented as an imaginary, future recovery from the most recent collapse, is at odds with the classical doctrines, but we see also that Morozov's different phases actually correspond to the altering of collapses (smutas) and recoveries encountered above.

The early twentieth-century "Breakdown" (nadlom) and its corresponding smuta during the 1917 Revolutions was for Morozov the result of the work of "antiRussian forces." His view of the Soviet period is overall a negative one, but his account of the Soviet Union is mostly devoted to the initial revolutionary period (and contains conspicuously little on Stalin), while the 1990s are nevertheless

\footnotetext{
${ }^{8}$ For a discussion of the temporality of the classical doctrines, see Mjør (2017, 45-48).
} 
described as the "destruction of a great land" and a tragic period for the "indigenous Orthodox people of a great Eurasian power," i.e. the Soviet Union. The book ends with the expression of a firm belief in the rebirth of Russian civilization, a belief based explicitly on the indigenous cyclical model developed by post-Soviet thinkers such as Aleksandr Panarin and Natalia Narochnitskaia, who are quoted extensively, rather than on the classical model. In Morozov's words, the "time of chimera" (a notion taken from Lev Gumilev) must be succeeded by the "time of rebirth" in order for the smuta of the 1990s to be overcome economically and culturally (Morozov 2014, 13-19, 303, 362, 378-379).

Mikhail Stepashkin is the author of books such as The History of Russian Smutas and Contemporary Realities (2008), The History of Russia and the Ascetics of Russian National Civilization (2010), and the like. He describes his own methodology as centered on the "repetitiveness and harmonization of historical events," which enables the prognostication and evaluation of history. His 2008 book on Russian smutas is an account of the three crises that took place in the early seventeenth century, the early twentieth and late twentieth centuries, and these have always, according to Stepashkin, been the result of Western expansion towards Russia. The struggle against the West has likewise been accomplished by the people itself-it has been a fight "for moral values, Orthodox faith, the recovery of traditions, justice, i.e., the continuation of power and the expulsion of occupants" (the treacherous elites). "So-called civil wars" were, according to Stepashkin, actually popular revolts against anti-Russian forces-that in 1992 were armed with weapons such as vouchers-with the aim of liberating the nation. "Historical conditions, as we know, repeat themselves: The same Russian-national protest took place in the first quarter of the twentieth century, where it failed, while in the 1990s this national-Russian constructive protest had to move to the underground" (Stepashkin 2008, 101-104). The book is explicitly conspiratorial and even antiSemitic, making several references to the Protocols of the Elders of Zion. At the same time, it ends in a quasi-scientific mode that visualizes Russian history by means of exact curves from which a mathematical formula is derived (see Fig. 2). The model is structurally similar to that of Khelga, but the message is radically different.

Thus, the accounts of Redkozubov/Sokolov, Morozov and Stepashkin are examples of how classical civilizational doctrines are extensively evoked, cited, and put into circulation. The authors thereby situate themselves in what they see as longstanding and vital traditions of civilizational thinking. However, the historical models structuring their accounts are not in keeping with the classical models but are rather developed with reference to allegedly analogous events in Russian history. This discrepancy can be observed also in less explicitly patriotic texts than those discussed above (e.g. Gorin 2011, 147-175), but which nevertheless contributes to the persistence of a civilizational discourse centered on Russia as a civilization of its own, with its own historical logic. This raises, in turn, the question whether the latter, "smuta model" is more indigenous in the sense that it seeks to evaluate Russian history not according to models of Western origin. Or does it after all remain indebted to the West as the "other"? As we have seen, alleged Western 


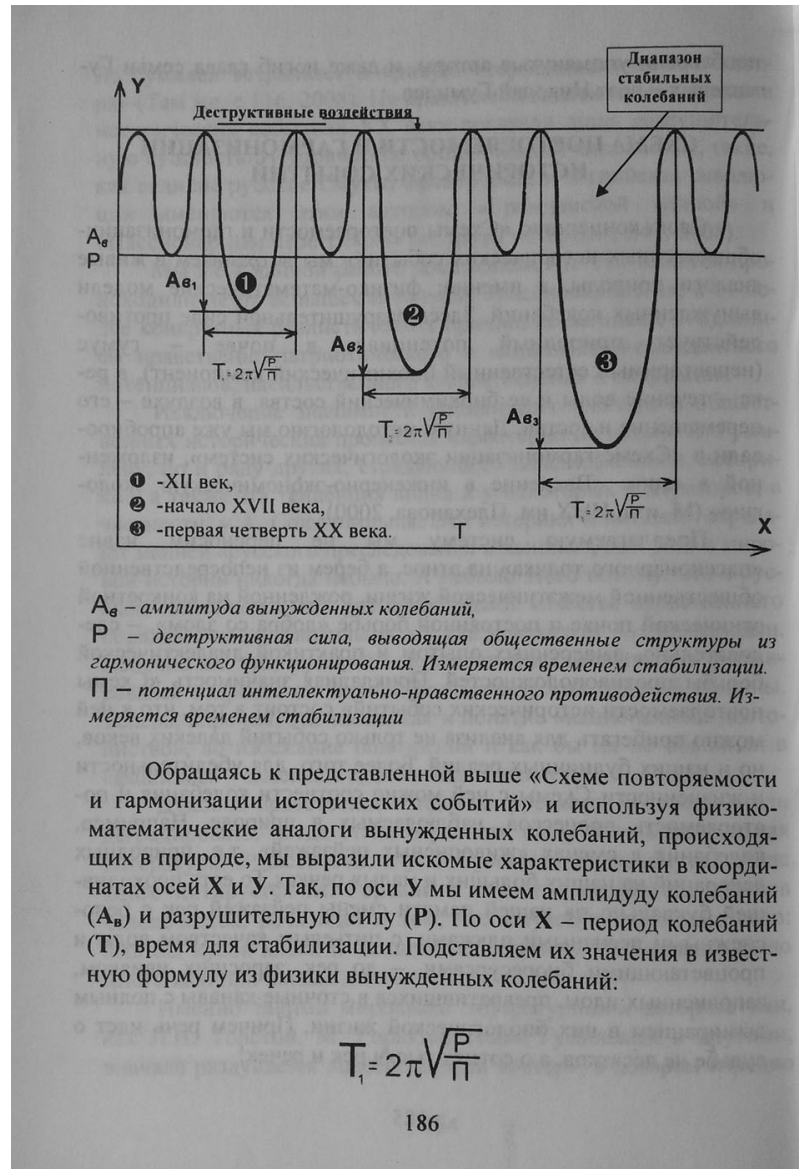

Fig. 2 (Stepashkin 2008, 186)

interventionism plays a key role in the conservative understanding of smuta. A case for a further discussion of this issue is provided by the ideology of the Izborsk Club.

\section{The western temptation (The Izborsk Club)}

The notion of recurrent smutas plays a central role in the ideology of the Izborsk Club, a neoconservative think-tank founded in 2012 and led by the writer and outspoken neo-imperialist, Aleksandr Prokhanov. A major task of this club is to consolidate the patriotic camp in Russia, in particular the so-called "white" and "red" fractions, i.e. the defenders of tsarist Russia and the supporters of the Soviet Union by means of a new state ideology for Russia that is capable of uniting these two positions (Laruelle 2016). In the post-Soviet context, however paradoxical it may sound, the pro-Soviet mind-set fundamentally shares with the white, pro-tsarist 
outlook an antirevolutionary stance. As the Izborsk leadership sees it, both traditions have defended a great Russia_-above all against the Westernizers and liberals.

The Izborsk understanding of Russian history is actively disseminated in the journal Izborsk Club: Russian Strategies, and in the following I will analyze texts from the third issue of 2013, which is devoted precisely to the "reconciliation" and "union of Reds and Whites" (Aver'ianov et al. 2013). ${ }^{9}$ A key contributor to this issue is Vitalii Averianov, previously one of the authors of the "Russian Doctrine" manifesto, published in 2007 by the Centre of Dynamic Conservatism, a forerunner of the Izborsk Club. In that text as well the notion of smuta in the plural plays an important role (Aver'ianov et al. 2007).

The Izborsk members combine, furthermore, the concept of smuta with Prokhanov's (another key contributor to the issue) notion of the Fifth Empire. The five Russian empires according to Prokhanov are Kiev, Muscovy, the Romanov empire, the Soviet Union, and post-Soviet Russia. Except for the shift from the first to the second, they are all separated from one another by Times of Troubles, a pattern that Averianov presents as a methodological framework for analyzing Russian history, or what he calls the "Conception of three smutas" (Kontseptsiia trekh smutnykh vremen, 40). Similar to Khelga, the Izborsk Club sees the three smutas as having been carried out by similar, almost-identical protagonists, except for that they were either of foreign origin or "foreign agents"/"fifth columnists." The main actors (or "types," tipazhy, 96-99) according to the Izborsk Club may be schematized as follows ${ }^{10}$ :

\footnotetext{
${ }_{9}$ In the following I refer to several texts of this issue, some of which are collectively written, some individually, and I have for the sake of simplicity inserted the page number only.

10 The Russian terms for the seven different types are: Vneshnye zakazchiki, Kuratory (predstaviteli zakazchika), Prodiusery-organizatory, Ideology, Proektirovshchiki-aferisty, Samozvantsy-kharizmatiki, Okruzhenie samozvantsev - oligarkhat.
} 


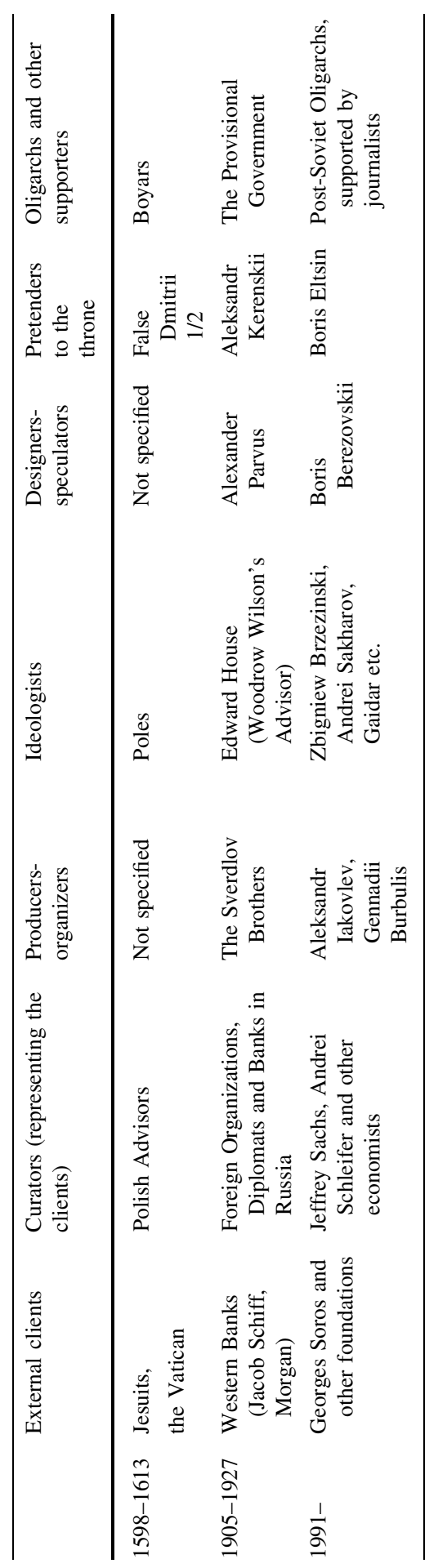


And since the historical actors of different periods correspond to one another, so do historical events: "The February attempt was repeated 74 years later" (51).

The Izborsk Club defines Russia as a civilization of its own (Laruelle 2016, 631), a notion that they, too, combine with a cyclical historical model. While independent, civilizations do nevertheless continually enter into conflict with one another. According to the Izborsk Club, the world is a stage where civilizations clash, and these clashes result in turn in "revolutions and smutas" (50). A central, selfimposed task for the Izborsk Club is therefore to prevent another smuta on Russian soil. Smuta is, in their worldview, the result of foreign intervention, either directly or by means of "fifth columns" (57). Smutas are "antisystems" initiated by a parasite-like "small nation," a formulation that combines concepts originally coined by Lev Gumilev and Igor Shafarevich respectively. Recurrent smutas splinter Russian history making it difficult to obtain an integral perspective on it (38-39).

The paradox that emerges from the Izborsk texts, however, is that what makes Russian history meaningful is smutas and their overcoming. They are the events that dramatize it, without which it would have been static. (History without events is a theoretical model among scholars, but difficult to imagine as capable of mobilizing politically.) In one place we read that in the early days of perestroika there arose the possibility of a transition to the Fifth Empire "without smuta" (51), but it is difficult to understand how a new empire might arise without the collapse of the former one. More importantly, without Russia's imaginary victory over various forms of foreign intervention its history would have been less appealing. Thus, the Izborsk conception of Russian civilization with a cyclical history of recoveries is clearly dependent on an imaginary West and the threats that it represents. It is the painful encounters with the West that provides Russian history with a purpose.

The interpretation of Stalin is particularly illustrative in this respect. The second smuta ended when Stalin finally took over; Lenin, although not included in the scheme above, represents the destruction of imperial Russia. By contrast, Stalin's main achievements according to the Izborsk Club began with the 1932 legislation against abortion and homosexuality, where the party demonstrated that it played a "moral function similar to the church." This was followed by the rejection of former Bolshevik internationalism (the Pokrovskii school in historiography; the old party elite during the Great Terror), the rejection of the Leninist idea of the withering away of the state, a new appraisal of the ancient Russian past, the disbanding of the Comintern, and the postwar campaign against cosmopolitanism. These measures testify to Stalinist Russia's "consistent evolution away from 'revolutionary antisystem' to a Russian civilizational project” (67). By implication, it was the revolutionary smuta that provided the Russian civilization with new tasks.

As Sergei Prozorov has shown, the post-Soviet rehabilitation of Stalin is grounded in an interpretation of Stalin as having vanquished revolutionary chaos (Prozorov 2016, 1-37). Although Prozorov does not discuss the smuta metaphor, the currently prevailing anti-revolutionary version of Stalin is in line with the affirmative perspectives on Russian history discussed in this article, and it is particularly dominant in the writings of the Izborsk Club, in which Stalin is praised as the founder of a new imperial order. 
According to the Izborsk Club, Russia is currently still struggling with the legacy of the "third smuta": loss of territories, economic problems, tacit support for the "Washington consensus," liberalism, and traditional values under threat. The task for Russia is to once again become "one and indivisible." However, the new, Fifth Empire should not only combine the most valuable components of the preceding ones, but even introduce new elements in the history of Russian empires, such as a decisive undermining of global Western hegemony and an integration within Eurasia beyond the borders of the former Soviet Union (72-75). Hence it is precisely the cyclical character of Russian history, brought about by "foreign agents," that enables this new, unprecedented empire. Smuta means, according to Averianov, a rejection of the integrity of Russian history (93), but the same thing may be said of the very conception of five empires and three smutas. Times of Troubles, in short, make Russian history meaningful.

Several members of the Izborsk Club have frequently used smuta as a framework for describing Russian state collapse and foreign intervention (e.g. Starikov 2017). My final example is the academic and public intellectual Andrei Fursov. In 2001, he proposed a cyclical scheme of Russian history similar to many of those encountered above (Fursov 2001), while his 2016 book, The Question of Struggle in Russian History, collects his most recent texts and interviews related to the three Russian smutas (early seventeenth, early twentieth, and late twentieth centuries). In his own words, this story begins with the "first Western intervention" and culminates with the "financial-economic and information-psychological (psycho-historical) intervention, accomplished by the West as an ally of specific powers and structures of late Soviet society at the turn of the 1990s" (Fursov 2016, 6). ${ }^{11}$ In his book, Fursov sets out to present the defining features and logic of the recurrent smutas, which are compared to each other throughout the book in order to expose their common "mechanism" and thus the underlying "boomerang" of history (Fursov 2016, 96).

Smutas according to Fursov last as a rule for three decades. They are always elicited by the "betrayal" of the upper ranks, or the "boyars," be it in the seventeenth century or under Gorbachev and Eltsin. Thus, the first smuta provides the blueprint for the succeeding ones, all of which possess the following five characteristics: (1) the loss of a unified central power (or the emergence of dual power); (2) a top-down spread of the crisis from the upper segments of society; (3) the combination of class and national struggle, the latter, however, becoming increasingly the most important one, "from smuta to smuta"; (4) the crucial role played by the West with the persistent aim of eliminating Russia as a geopolitical and geo-economic competitor and gaining control over its resources; (5) its integrated role in world-wide crises. The lesson of the recurrent smutas is therefore that one must explore and expose the elites, various external forces and, not least, Russia's own "fifth columnists." However, Russia is always saved by national unity, which is more fundamental than class unity. And while crises are a major threat, Fursov presents them also as possibilities for national renewal, hence their fascination (Fursov 2016, 10, 16). Although Fursov does not deny the importance of

\footnotetext{
11 Pagination here and below is given according to the pdf version provided by the ebookstore Litres.ru, which differs from the printed version of Fursov's book.
} 
internal class conflicts and factors such as hunger-the latter being a critical aspect of all Russian smutas - they are always the result of elite betrayal and external aggression, not of struggles from below.

Fursov presents a model for the regularities of Russian history, a model that is nevertheless ambiguous in terms of politics: "we may hope," he writes, that the current, ongoing smuta will be overcome, but we also need to struggle in order to survive as a nation (Fursov 2016, 10). By implication, Fursov's texts display on the one hand a firm belief in the manifest logic of history, an assumption carrying clear metaphysical overtones, and on the other hand an anxiety that this logic will not save us this time. As in the other Izborsk texts, however (cf. above), pessimism and despair are also means of forging new identities and ties. While the recurrent Times of Troubles represent historical failures and discontinuity, they are turned into a positive feature. What we witness here is a "positivization of lack" (Oushakine $2009,207)$, even in cases where the lack is the result of alleged foreign intervention.

\section{Conclusions}

While the notions of smuta presented in this paper differ sharply from one another in at least one respect, being either the result of a systemic and thus an internal crisis (the liberal interpretation) or of foreign intervention (the conservative), ${ }^{12}$ the form and even the content are conspicuously similar. Both distinguish firmly between a cyclical and a linear-progressive understanding of history, attributing opposite values (+/-) to them. With the possible exception of Iakovets, neither makes provisions for alternative kinds of historical development. Moreover, the two models present us with roughly the same sequence of events, the main difference being that the cycles of Russian history are explained by means of different types of plots and in different ways ideologically. While the liberal critique is "satirical" and presents no clear, persuasive solutions to the problems of Russian history, the conservative interpretation is "comic" in that it foresees new recovery-though the emergence of yet another smuta represents a constant threat. ${ }^{13}$ There is, in other words, a fundamental structural similarity between them, but it is important to note here that the liberal critique historically came first and that the conservative response is an affirmative reinterpretation of its scheme. It remains therefore heavily indebted to the liberal, Westernized understanding of the Russian past and is a response to it.

As claimed several times in the issue of the Izborsk Club Journal discussed above, the Fifth Empire will be a project of decolonization-smuta also means "colonialism" (30, 71, 75, 93) - but as I have tried to show above it remains dependent on the West in several ways. This means that Russian symbolic decolonization shares several characteristics with genuine, third-world processes of

\footnotetext{
12 The latter is also the meaning of smuta in the "New Chronology" of Nosovskii and Fomenko (2008), except that they do not praise the Romanov Empire as a recovery, but rather claim that it was a treachery.

13 I am making use here of Hayden White's typology of the basic forms of historical narratives, or "emplotment" (explanation by narrative). Correspondingly, the liberal critique is contextualist in its manner of argumentation, while the conservative is organicist (White 1973).
} 
decolonization and their anticolonial justification. On the one hand, its narrative is adopted from Russian westernizers. On the other, without an imaginary West Russian history as the realization of a Fifth Empire or the like would have been unimaginable. From Panarin to Fursov, smuta and its overcoming is the key to understanding Russian history, and Russia is therefore simply unimaginable without these "foreign interventions." For the liberal approach, to involve the West as a benchmark is probably acceptable. For the conservative approach, however, it inevitably appears self-contradictory. According to contemporary Russian conservatism (e.g., Leont'ev and Nevzorov 2008), Russia is a (besieged) "fortress" and yet so vulnerable to influence from the outside. And to apply a model structurally similar to the Westernizing interpretation suggests that it is challenging to conceptualize Russia outside a Eurocentric framework- to provincialize Europe from within Russia is apparently a difficult task.

Open Access This article is distributed under the terms of the Creative Commons Attribution 4.0 International License (http://creativecommons.org/licenses/by/4.0/), which permits unrestricted use, distribution, and reproduction in any medium, provided you give appropriate credit to the original author(s) and the source, provide a link to the Creative Commons license, and indicate if changes were made.

\section{References}

Akhiezer, A. (1997). Rossiia: Kritika istoricheskogo opyta (Vol. 2). Novosibirsk: Sibirskii Khronograf. Akhiezer, A. (2001). Tsivilizatsionnaia spetsifika rossiiskogo obshchestva. In M. P. Mchedlov et al. (Eds.), Rossiiskaia tsivilizatsiia: Slovar'. Moscow: Respublika.

Akhiezer, A. (2006). Trudy. Moscow: Novyi Khronograf.

Al'bedil', M. F., \& Savinov, D. G. (Eds.). (2013). Tsiklichnost': Dinamika kul'tury i sokhranenie traditsii (p. 2013). MAE RAN: St. Petersburg.

Atnashev, T. (2015). "Reformatory v poiskakh iazyka: Kniga Egora Gaidara 'Gosudarstvo i evoliutsiia'." Novoe literaturnoe obozrenie 5, 119-139.

Aver'ianov, V. et al. (2007). "Russkaia doktrina." http://www.rusdoctrina.ru/page95507.html.

Aver'ianov, V. et al. (2013). Zhurnal Izborskii Klub: Russkie strategii 3.

Baburin, V. L., \& Chistiakov, P. A. (Eds.). (2007). Prostranstvo tsiklov: Mir-Rossiia-Region. Moscow: LKI. Bazhanov, V. A. (1999). A note on A.S. Panarin's Revansh istorii. Europe-Asia Studies, 51(4), 705-708.

Chakrabarty, D. (2000). Provincializing Europe: Postcolonial thought and historical difference. Princeton: Princeton University Press.

Cooper, F. (2005). Colonialism in question: theory, knowledge, history. Berkeley: University of California Press.

Fursov, A. I. (2001). "Russkaia vlast', Rossiia i Evraziia: Velikaia Mongol'skaia derzhava, samoderzhavie i kommunizm v bol'shikh tsiklakh istorii (très-très grand espace dans une très-très longue durée)." Russkii istoricheskii zhurnal 4, 15-114.

Fursov, A. I. (2016). Voprosy bor'by v russkoi istorii: Logika namerenii i logika obstoiatel'stv. Moscow: Knizhnyi mir.

Gaidar, E. T. (2009). "Rezhim mozhet rukhnut' neozhidanno, za dva dnia,” Novaia gazeta. November 20.

Gaidar, E. T. (2010). Smuty i instituty; Gosudarstvo i evolutsiia. St Petersburg: Norma.

Gerasimov, I., Glebov, S., \& Mogilner, M. (2013). The postimperial meets the postcolonial: Russian historical experience and the postcolonial moment. Ab Imperio, 2, 97-135.

Gorin, D. G. (2011). Prostranstvo i vremia v dinamike rossiiskoi tsivilizatsii. Moscow: URSS.

Gvozdev, A. V. (2016). Pravoslavno-slavianskaia tsivilizatsiia v geopoliticheskikh ucheniiakh noveishego vremeni. Moscow: Prometei.

Iakovets, Iu. V. (1999). Tsikly. Krizisy. Prognozy. Moscow: Nauka.

Iakovets, Iu. V. (2000). Budushchee Rossii v koordinatakh evraziiskoi tsivilizatsii. Obshchestvo $i$ ekonomika, 1, 18-35. 
Ioann, Mitropolit Sankt-Peterburgskii i Ladozhskii. (1995). Odolenie smuty: Slovo k russkomu narodu. St Petersburg: Tsarskoe delo.

Kara-Murza, S. G. (2011). Rossiia i zapad: Paradigmy tsivilizatsii. Moscow: Akademicheskii proekt.

Khel'ga, O. (2012). Spiral' russkoi tsivilizatsii: Istoricheskie paralleli i reinkarnatsiia politikov: Politicheskoe zaveshchanie Lenina. Moscow: Tsentrpoligraf.

Kholmogorov, E. (2016). Revansh russkoi istorii. Moscow: Knizhnyi mir.

Laruelle, M. (2004). The discipline of culturology: A new 'Ready-Made Thought' for Russia. Diogenes, 51(4), 21-36.

Laruelle, M. (2016). The Izborsk Club, or the New Conservative Avant-Garde in Russia. Russian Review, $75,626-644$.

Leont'ev, M. (2005). “Restavratsiia budushchego Rossii.” Komsomol'skaia Pravda, April 26.

Leont'ev, M., \& Nevzorov, A. (2008). Krepost' Rossii. Moscow: Eksmo.

Linde, F. (2016). The civilizational turn in Russian political discourse: From Pan-Europeanism to civilizational distinctiveness. Russian Review, 75, 604-625.

Medushevsky, A. (2013). Conservative political romanticism in post-Soviet Russia. In E. Namli, S. Hedlund, \& P.-A. Bodin (Eds.), Power and legitimacy: Challenges from Russia. London: Routledge.

Mjør, K. J. (2017). A morphology of Russia? The Russian civilisational turn and its cyclical idea of history. In A. Mustajoki \& K. Lehtisaari (Eds.), Philosophical and cultural interpretations of Russian Modernisation. London: Routledge.

Morozov, B. V. (2014). Russkaia tsivilizatsiia i sud'ba pravoslavnoi Rossii. Moscow: Obshchestvo druzhby i razvitiia sotrudnichestva s zarubezhnymi stranami.

Morozov, V. (2015). Russia's postcolonial indentity: A subaltern empire in a eurocentric world. Basingstroke: Palgrave.

Nosovskii, G. V., \& Fomenko, A. T. (2008). Velikaia smuta: Novaia khronologiia dlia vsekh. Moscow: Astrel'.

Oushakine, S. A. (2009). Patriotism of despair: Nation, war and loss in Russia. Ithaca: Cornell University Press.

Panarin, A. S. (2005). Revansh istorii: Rossiiskaia strategicheskaia initsiativa v XXI veke. Moscow: Russkii mir.

Petersson, B. (2013). The eternal great power meets the recurring Time of Troubles: Twin political myths in contemporary Russian politics. European Studies, 30, 301-326.

Pomerants, G. S. (1998). Strastnaia odnostoronnost' $i$ besstrastie dukha. St Petersburg: Universitetskaia kniga.

Prozorov, S. (2016). The biopolitics of stalinism: Ideology and life in Soviet Socialism. Edinburgh: Edinburgh University Press.

Putin, V. (2012). "Rossiia: Natsional'nyi vopros.” Nezavisimaia gazeta, January 23.

Redkozubov, S. A., \& Sokolov, N. V. (2008). Istoki, sut' $i$ sud'ba russkoi tsivilizatsii. Moscow: Obshchestvo druzhby i razvitiia sotrudnichestva s zarubezhnymi stranami.

Remizov, M. (2005). "Proekt 'gosudarstvo-tsivilizatiia'." Agenstvo politicheskikh novostei, February 9.

Scherrer, J. (2003). Kulturologie: Russland auf der Suche nach einer zivilisatorischen Identität. Essen: Wallstein.

Shnirel'man, V. (2007). Tsivilizatsionnyi podkhod kak national'naia ideia. In M. Laruelle (Ed.), Sovremennye interpretatsii russkogo natsionalizma. Stuttgart: Ibidem.

Starikov, N. V. (2017). Russkaia smuta XX veka. St Petersburg: Piter.

Stepashkin, M. A. (2008). Istoriia Russkikh Smut v sovremennykh realiakh. Moscow: Grafikon.

Swiderski, E. (2010). The cultural hermenutic of Russia's cultural experience: The case of Aleksandr Samojlovič Akhiezer. Studies in East European Thought, 62(3-4), 279-298.

Torbakov, I. (2014). The Russian orthodox church and contestations over history in contemporary Russia. Demokratizatsiya, 22(1), 145-170.

Verkhovskii, A., \& Pain, E. (2010). Tsivilizatsionnyi nationalizm: Rossiiskaia versiia 'Osobogo puti'. In E. Pain (Ed.), Ideologiia 'osobogo puti' v Rossii $i$ Germanii: Istoki, soderzhanie, posledsviia. Moscow: Tri kvadrata.

White, H. (1973). Metahistory: The historical imagination in nineteenth-century Europe. Baltimore: John Hopkins University Press.

Yanov, A. (1978). The drama of the Time of Troubles, 1725-30. Canadian-American Slavic Studies, 12(1), 1-59.

Young, R. J. C. (2003). Postcolonialism: A very short introduction. Oxford: Oxford University Press. 